\title{
Activation In Vitro of Rheumatoid \\ Synovial Collagenase from Cell Cultures
}

\author{
Carol A. Vater, Carlo L. Mainardi, and Edward D. Harris, Jr., Department of \\ Medicine Dartmouth-Hitchcock Medical Center, Hanover, \\ New Hampshire 03755
}

\begin{abstract}
A B S T R A C T Rheumatoid synovial cells dissociated from matrix and adherent to culture dishes released a latent form of collagenase into culture medium. Previous studies have shown that the latent enzyme does not complex with $\alpha_{2}$-macroglobulin and binds to fibrillar substrate. We now show that serum-free culture medium of the synovial cells contains an inhibitor of collagenase as well as latent enzyme; the two were separated on a column of acrylamide/agarose. Latent collagenase (estimated mol wt 45,000-49,000) was transformed by trypsin to active collagenase of $\cong \mathrm{mol}$ wt 33,000 . When mixed with inhibitor the active enzyme formed an inactive complex again with $\cong \mathrm{mol}$ wt 45,000-49,000. The inhibitor(s) itself was found in one major peak of mol wt 33,000-35,000 and several minor peaks eluting with lower apparent molecular weight. Mersalyl, an organic mercurial compound, effectively activated latent collagenase producing an active enzyme with $\cong$ mol wt 33,000 . Bacterial collagenase did not activate latent enzyme. We suggest that latent rheumatoid synovial collagenase, as it is harvested from synovial cells in culture, is an enzymeinhibitor complex.
\end{abstract}

\section{INTRODUCTION}

Collagenase associated with rheumatoid synovial tissue has been implicated in the pathogenesis of the proliferative, destructive component of this disease $(1,2)$. The enzyme has been purified and characterized (3-5). It is active maximally at $\mathrm{pH} 7.0-8.0$, is inhibited by chelating agents and thiol compounds, and has an estimated mol wt of 33,000 . Initially the enzyme was found active in the culture medium from explants of synovial tissue (3-5). More recently, with dissociated adherent cells from tissue removed at the time of

Dr. Mainardi was a postdoctoral Fellow of The Arthritis Foundation.

Received for publication 11 May 1978 and in revised form 13 July 1978 synovectomy or arthroplasty on rheumatoid joints, it has become apparent that the enzyme is in a latent form in the culture medium of cells incubated in the absence of serum (6) as well as in medium with serum added (7). It has been shown that in latent form the rheumatoid synovial collagenase (RSC) ${ }^{1}$ was resistant to complexing with $\alpha_{2}$-macroglobulin (6) (the principal collagenase inhibitor in plasma), that it could bind in latent form to fibrillar substrate (8), and subsequently be activated by plasmin which in turn is generated from plasminogen through action of a plasminogen activator produced by the synovial cells (6).

Despite this evidence for a pathway by which the inactive RSC might be activated in vivo, very little is known about the nature of the latent enzyme. The present studies show that latent RSC found in serum-free culture medium has associated with it an effective inhibitor of activated RSC, and that latent RSC at $\cong \mathrm{mol}$ wt 47,000 may be effectively transformed in vitro by an organic mercurial compound to active collagenase of mol wt 33,000.

\section{METHODS}

Materials were purchased from the following sources: tissue culture flasks (plastics) from Flow Laboratories Inc. Rockville, Md.; Dulbecco's modified Eagle's medium, fetal calf serum, lactalbumin hydrolysate, penicillin, streptomycin, and L-glutamine from Grand Island Biological Co., Grand Island, N. Y.; rabbit anti-bovine serum from N. L. Cappell Laboratories Inc., Cochranville, $\mathrm{Pa}$.; columns for gel chromatography from Pharmacia Fine Chemicals, Piscataway, N. J.; acrylamide agarose beads (Ultrogel AcA 54 and AcA 34) from LKB Instruments Inc., Rockville, Md.; pressure filtration apparatus and UM-10 membranes from Amicon Corp., Lexington, Mass.; trypsin-TPCK (L-1-tosylamido-2-phenylethyl chloromethylketone), bacterial collagenase (CLS and CLSPA), soybean trypsin inhibitor, and pepsin from Worthington Biochemical Corp., Freehold, N. J.; mersalyl (0-[[3-(hydroxymercuri)-2-methoxypropyl]carbamoyl]phenoxyacetic acid)

${ }^{1}$ Abbreviations used in this paper: AcA 54, acrylamide/ agarose; RSC, rheumatoid synovial collagenase; $\mathrm{V}^{\mathrm{E}}$, elution volume; $\mathrm{V}^{\mathrm{T}}$, bed volume. 
and bovine serum albumin from Sigma Chemical Co., St. Louis, Mo.; 4-chloromercuribenzoate (sodium salt) and urokinase from Calbiochem, San Diego, Calif.; p-aminophenylmercuric acetate from Aldrich Chemical Co., Milwaukee, Wis.; $\left[{ }^{14} \mathrm{C}\right]$ glycine and $\left[{ }^{14} \mathrm{C}\right]$ proline from New England Nuclear, Boston, Mass.; dialysis membranes from Union Carbide Corp. New York; materials for acrylamide slab gel electrophoresis from Bio-Rad Laboratories, Richmond, Calif.; and ovalbumin, chymotrypsinogen $A$, and ribonuclease $A$ from Pharmacia Fine Chemicals.

\section{Preparation of RSC from cultures of rheumatoid synovial cells}

Cultures of adherent rheumatoid synovial cells were prepared by established methods (7). After cells reached confluence $\left(\cong 10^{5}\right.$ cells $\left./ \mathrm{cm}^{2}\right)$, the cells were washed three times in Hanks' balanced salt solution, and cultures were continued in Dulbecco's modified Eagle's medium plus 0.2\% lactalbumin hydrolysate without added serum. Penicillin, streptomycin, and L-glutamine were added fresh to all culture media. Medium was harvested and stored frozen as described (6). After thawing at room temperature, pooled media or that concentrated by pressure dialysis at $4^{\circ} \mathrm{C}$ was used for enzyme studies.

\section{Assays}

Collagenase. Both unlabeled and radioactive guinea pig skin collagens were purified by established methods $(9) .{ }^{14} \mathrm{C}-$ labeled collagen $(10,000 \mathrm{dpm} / \mathrm{mg})$ was obtained by injecting guinea pigs before sacrifice with $\left[{ }^{14} \mathrm{C}\right]$ glycine and $\left[{ }^{14} \mathrm{C}\right]-$ proline. Collagenase assays were performed with 50-100 $\mu \mathrm{l}$ reconstituted ${ }^{14} \mathrm{C}$-labeled collagen fibrils as substrate (10). 1 collagenase $\mathrm{U}$ equals $1 \mu \mathrm{g}$ collagen in fibril form degraded/ min at $37^{\circ} \mathrm{C}$. Collagenase was also assayed in viscometers at $27^{\circ} \mathrm{C}$ and $35^{\circ} \mathrm{C}$ as described previously (11). L-Arginine $(0.05 \mathrm{M})$ was added to inhibit fibril formation (12) at the higher temperature. Reaction products of collagenase were examined by electrophoresis in $7.5 \%$ acrylamide slab gels containing sodium dodecyl sulfate (13).

\section{Gel filtration chromatography of synovial collagenase}

Ultrogel AcA 54 was washed extensively and degassed in $0.1 \mathrm{M}$ Tris- $\mathrm{HCl}, \mathrm{pH} 7.6,0.7 \mathrm{M} \mathrm{NaCl}$, and $0.005 \mathrm{M}$ $\mathrm{CaCl}_{2}$. Sodium azide $(0.02 \%)$ was added to all buffer solutions to retard bacterial growth. The beads were poured into a $1.5 \times 90-\mathrm{cm}$ glass column and the column was pumped at $4^{\circ} \mathrm{C}$ at a constant rate $(12 \mathrm{ml} / \mathrm{h})$. Fractions were collected in plastic tubes which were weighed $( \pm 0.1 \mathrm{mg})$ before and after collection. The column was calibrated for molecular weight determinations with standard compounds (bovine serum albumin, ovalbumin, chymotrypsinogen $\mathrm{A}$, and ribonuclease $\mathrm{A}$ ).

\section{Assays for inhibitors of collagenase}

Portions $(75 \mu \mathrm{l})$ of fractions pooled from the column were incubated with $75-\mu$ l portions of active rheumatoid synovial collagenase (either spontaneously active or activated by trypsin or plasmin) (vide infra) for $90 \mathrm{~min}$ at $35^{\circ} \mathrm{C} .100 \mu \mathrm{l}$ of this mixture was then incubated with $100 \mu \mathrm{l} 0.01 \mathrm{M}$ Tris$\mathrm{HCl}, \mathrm{pH} 7.6,0.03 \mathrm{M} \mathrm{CaCl}_{2}$, and $100 \mu \mathrm{l}(200 \mu \mathrm{g})\left[{ }^{14} \mathrm{C}\right]$ collagen fibrils at $37^{\circ} \mathrm{C}$ and soluble ${ }^{14} \mathrm{C}$-labeled peptides released into the liquid phase were counted as in other collagenase assays (10).

\section{Activation of latent collagenase}

Activation of latent collagenase was accomplished by enzymatic or nonenzymatic methods. Addition of trypsin (10$100 \mu \mathrm{g} / \mathrm{ml}, 30 \mathrm{~min}$, room temperature) followed by addition of a fourfold excess of soybean trypsin inhibitor had been shown previously $(6,7)$ to activate latent rheumatoid synovial collagenase. Samples also were activated with plasmin prepared by incubating $400 \mu$ l urokinase $(2,000 \mathrm{Ploug} \mathrm{U} / \mathrm{ml})$ with $1 \mathrm{mg}$ plasminogen prepared from canine plasma by affinity chromatography on lysyl-Sepharose (Sepharose, Pharmacia Fine Chemicals) (14). Nonenzymatic activation was achieved by using mersalyl under conditions described in Results.

\section{Purification of bacterial collagenase}

Partially purified bacterial collagenase was purchased from Worthington Biochemical Corp. (CLSPA, lot no. 54K405) and resuspended in $1 \mathrm{ml}$ of $0.05 \mathrm{M}$ Tris- $\mathrm{HCl}, \mathrm{pH} 7.6,0.01 \mathrm{M}$ $\mathrm{CaCl}_{2}$, and $0.02 \% \mathrm{NaN}_{3}$. A sample of $8 \mathrm{mg}$ was chromatographed on a calibrated $1.5 \times 90-\mathrm{cm}$ column of Ultrogel AcA 34 equilibrated in the same buffer. Column fractions were assayed for both collagenase activity $\left({ }^{14} \mathrm{C}\right.$-labeled collagen fibril substrate) and neutral proteinase activity (azocasein substrate) (15). A broad peak of collagenase activity was found in the column eluates; fractions eluting with high mol wt $(\geq 100,000)$ contained collagenase activity without azocaseinase activity and were pooled for further use.

\section{RESULTS}

Separation and recovery of collagenase inhibitor from collagenase. Culture medium was screened for both active and latent collagenase, and only those samples containing no active enzyme were used for the isolation of latent enzyme and inhibitor. After concentration by pressure filtration, this material was passed through the acrylamide/agarose (AcA 54) column and fractions that had less than $0.008 \%$ contamination with bovine serum with single radial immunodiffusion as a test system were obtained. A plot of $\log$ molecular weight of standard proteins vs. elution volume $\left(\mathrm{V}^{\mathrm{E}}\right) /$ bed volume $\left(\mathrm{V}^{\mathrm{T}}\right)$ was linear. The values for $\mathrm{V}^{\mathrm{E}} / \mathrm{V}^{\mathrm{T}}$ used to calibrate the abscissa in Figs. 1 and 3 correspond to the following mol wts: 0.38 $=80,000 ; 0.51=40,000 ; 0.63=20,000$. All procedures (concentration by pressure filtration of medium and gel filtration) were performed at $4^{\circ} \mathrm{C}$.

In the experiment shown in Fig. 1, 300 ml crude culture medium was concentrated 100 -fold and applied to the column. This starting sample contained $248 \mathrm{U}$ activatable collagenase and no spontaneously active enzyme. Approximately $66 \%$ of the activatable enzyme was recovered in fractions from the column (Fig. 1A); $0.6 \%$ of this was spontaneously active and all of it was found in fractions containing latent enzyme (Fig. 1A). This mixture of latent and high molecular weight active collagenase was followed by a major and several 


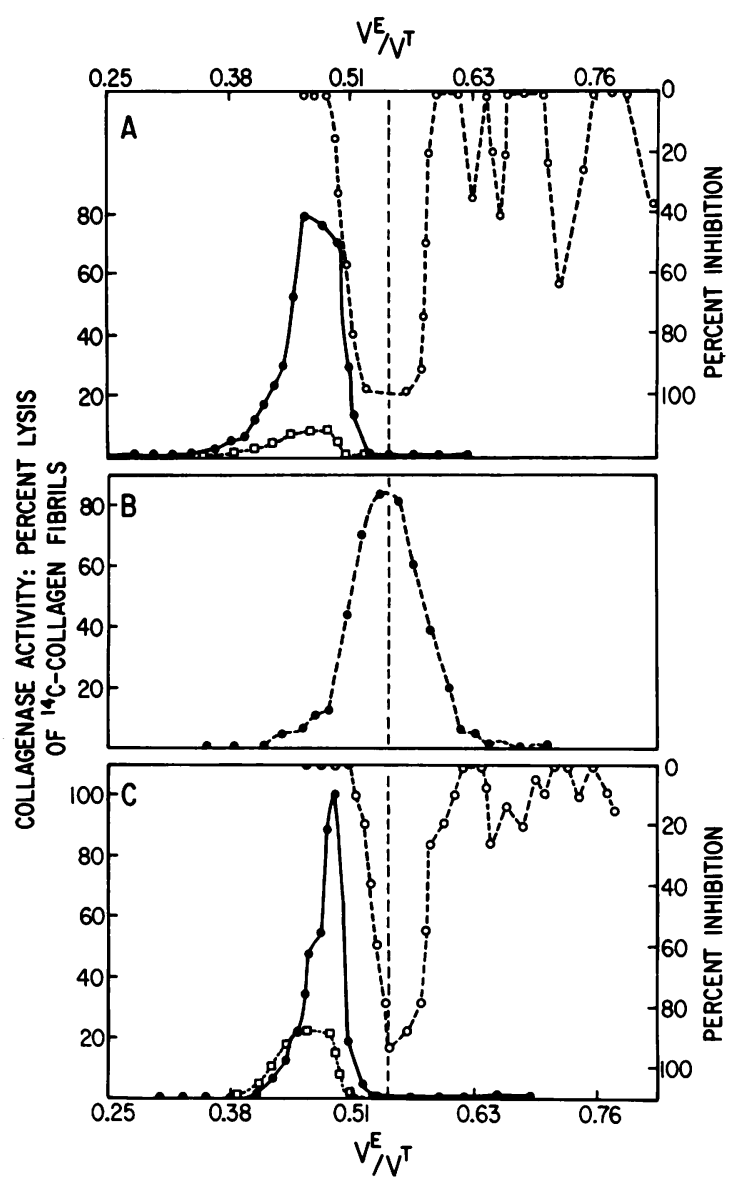

Figure 1 AcA 54 column used for isolation of enzyme and inhibitor from culture medium of rheumatoid synovial cells, calibrated as described in the text. For inhibition, read down on right ordinate; for collagenase activity, read up on left ordinate. (A) $248 \mathrm{U}$ collagenase, $100 \%$ in latent form, applied to column. Portions from each fraction were screened for spontaneously active collagenase, latent collagenase, and inhibitor. Latent collagenase assay $2.5 \mathrm{~h}, 37^{\circ} \mathrm{C}$. Active collagenase assay $21.5 \mathrm{~h}, 37^{\circ} \mathrm{C}$. (B) Sample applied was pooled latent collagenase from column in Fig. 1A after activation with trypsin $(30 \mu \mathrm{g} /$ $\mathrm{ml}, 30 \mathrm{~min}$ room temperature, followed by $120 \mu \mathrm{g} / \mathrm{ml}$ soybean trypsin inhibitor). Collagenase assays $11.5 \mathrm{~h}, 37^{\circ} \mathrm{C}$. (C) Sample applied was active collagenase pooled from column $1 B$ and pre-incubated with pooled inhibitor $\left(\mathrm{V}^{\mathrm{E}} / \mathrm{V}^{\mathrm{T}} 0.53-0.59\right)$ from column $1 \mathrm{~A}$ for $90 \mathrm{~min}$ at $35^{\circ} \mathrm{C}$. All fractions were screened for spontaneously active collagenase, latent collagenase, and inhibitory activity. Collagenase assays $33 \mathrm{~h}, 37^{\circ} \mathrm{C}$. latent collagenase (trypsin activatable); $\mathrm{O}_{---} \mathrm{O}$, inhibitory activity; - - - , collagenase activated by trypsin; $\square---\square$, spontaneously active collagenase.

minor peaks of inhibitory activity. We estimated the mol wt of the peak tubes containing latent enzyme to be $45,000-49,000$. The major peak of inhibitory material eluted in fractions consistent with mol wt of 32,00035,000 . Multiple small peaks of inhibitory activity were in fractions containing proteins of mol wt estimated to be $20,000,17,000$, and 11,000-12,500. The materials applied to the column contained very little protein and continuous monitoring of the eluate at $280 \mathrm{~nm}$ showed too little absorbance to include on Figs. 1 or 3 . When culture medium from rheumatoid cells incubated in the presence of $5 \%$ fetal calf serum (sufficient to inhibit all active enzyme) was passed over the AcA 54 column, latent collagenase was eluted in the same volume as when serum-free medium was used.

Shift in apparent molecular weight during inactivation to latent collagenase. Latent collagenase pooled from a column which had yielded latent enzyme and inhibitor (Fig. 1A) was activated with trypsin $(30 \mu \mathrm{g} / \mathrm{ml})$ and subsequently rerun through the AcA 54 column. The active enzyme eluted in peak fractions with $\cong$ mol wt 33,000 (Fig. 1B).

The pool of activated collagenase $\left(\mathrm{V}^{\mathrm{E}} / \mathrm{V}^{\mathrm{T}}=0.50\right.$ to $0.61)$ was incubated with inhibitor pooled from the major inhibitor peak of the original column (Fig. 1A, $\mathrm{V}^{\mathrm{E}} / \mathrm{V}^{\mathrm{T}}=0.53$ to 0.59 ) for $90 \mathrm{~min}$ at $35^{\circ} \mathrm{C}$. No spontaneously active collagenase could be demonstrated. This mixture was passed through the column. The results are recorded in Fig. $1 \mathrm{C}$ and show that latent enzyme was regenerated with an apparent molecular weight corresponding closely to that of the original latent enzyme pool. Additional free inhibitor was present with $\cong$ mol wt 33,000 . Some spontaneously active enzyme was present under the peak of latent collagenase but none was present in active form at mol wt 33,000. The endogenous inhibitor was capable of inactivating spontaneously active collagenase as well as trypsin-activated enzyme. Trypsin inactivated or destroyed collagenase inhibitor, but inhibitor had no capacity to inactivate trypsin. Latent RSC was incubated with purified bacterial collagenase and the larger bacterial enzyme was separated from the latent enzyme on the column of AcA 54. Activation of the latent collagenase by trypsin with subsequent assay with collagen in solution showed that the bacterial collagenase did not activate the synovial enzyme suggesting that the inhibitor was not a collagen or gelatin fragment. The activated RSC produced reaction products which, when electrophoresed on acrylamide gels, were consistent with those produced by the mammalian, but not the bacterial enzyme.

Nonenzymatic activation of latent collagenase. As shown in Fig. 2, increasing the concentration or duration of incubation of mersalyl with latent collagenase resulted in progressive activation of the enzyme. In the experiment shown, a final concentration of $0.026 \mathrm{M}$ mersalyl for $2 \mathrm{~h}$ at $35^{\circ} \mathrm{C}$ was sufficient to activate latent collagenase to nearly the same degree as optimal conditions of trypsin. The activation conditions (mersalyl concentration and time of incubation) varied when different crude media were used. Reaction mixtures applied to acrylamide gels showed principally the specific products of collagenolysis expected of mammalian 


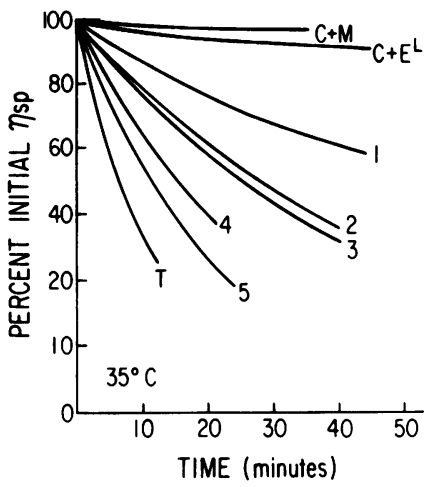

FIGURE 2 Activation of latent collagenase with mersalyl. Culture medium containing latent enzyme was incubated for varying lengths of time with different concentrations of mersalyl and subsequently assayed by viscometry at $35^{\circ} \mathrm{C}$. Each sample contained $292 \mu \mathrm{l} 0.1 \mathrm{M}$ Tris- $\mathrm{HCl}, \mathrm{pH} 7.6,0.7 \mathrm{M}$ $\mathrm{NaCl}, 0.005 \mathrm{M} \mathrm{CaCl}_{2}, 208 \mu \mathrm{l}$ pepsin-treated guinea pig skin collagen $(2 \mathrm{mg} / \mathrm{ml}), 83 \mu \mathrm{l} 0.5 \mathrm{M}$ L-arginine, $292 \mu \mathrm{l} 0.1 \mathrm{M}$ Tris$\mathrm{HCl}, \mathrm{pH} 7.6,0.03 \mathrm{M} \mathrm{CaCl}_{2}$, and $125 \mu \mathrm{l}$ of the sample to be assayed. $\mathrm{C}+\mathrm{M}=$ collagen $+0.15 \mathrm{M}$ mersalyl. $\mathrm{C}+\mathrm{E}^{\mathrm{L}}=$ collagen plus culture medium containing latent collagenase. (1) Culture medium $+0.0025 \mathrm{M}$ mersalyl, $35^{\circ} \mathrm{C}, 30 \mathrm{~min}$. (2) Culture medium $+0.015 \mathrm{M}$ mersalyl, $4^{\circ} \mathrm{C}, 23 \mathrm{~h}$. (3) Culture medium $+0.015 \mathrm{M}$ mersalyl, $35^{\circ} \mathrm{C}, 30 \mathrm{~min}$. (4) Culture medium $+0.015 \mathrm{M}$ mersalyl, $35^{\circ} \mathrm{C}, 70 \mathrm{~min}$. (5) Culture medium + $0.026 \mathrm{M}$ mersalyl, $35^{\circ} \mathrm{C}, 2 \mathrm{~h}$. (T) Culture medium $+10 \mu \mathrm{g} / \mathrm{ml}$ trypsin, $22^{\circ} \mathrm{C}, 30 \mathrm{~min}$, then $40 \mu \mathrm{g} / \mathrm{ml}$ soybean trypsin inhibitor. At $35^{\circ} \mathrm{C}$, reaction products of collagenase were degraded to gelatin, thereby losing virtually all measurable specific viscosity $\left(\boldsymbol{\eta}_{\mathrm{sp}}\right)$.

enzymes, the amino-terminal $75 \%$ fragment $\left(\mathrm{TC}^{\mathrm{A}}\right)$ and the carboxy-terminal $25 \%$ fragment $\left(\mathrm{TC}^{\mathrm{B}}\right)$. This indicated that there was little nonspecific proteinase activity in these reaction mixtures, because at $35^{\circ} \mathrm{C}$, $\mathrm{TC}^{\mathrm{A}}$ and $\mathrm{TC}^{\mathrm{B}}$ would denature to gelatin which is a suitable substrate for most proteinases. Fig. 3 summarizes the data obtained when enzyme was passed through the AcA 54 column before and after activation with mersalyl. Almost all of the collagenase present in the starting material was in latent form and was eluted with an apparent mol wt of 45,000-49,000 (Fig. 3A). Another portion of the same culture medium was incubated with mersalyl $(0.032 \mathrm{M})$ for $1 \mathrm{~h}$ at $35^{\circ} \mathrm{C}$, a procedure which maximally activated the enzyme. That material was eluted from the AcA 54 column in $0.002 \mathrm{M}$ mersalyl entirely in fractions of lower molecular weight appropriate for the active form (Fig. 3B). No latent enzyme in higher molecular weight fractions was found. Subsequent treatment of mersalylactivated collagenase with trypsin served only to decrease substantially the amount of enzyme recovered, consistent with our frequent observation that trypsin often inactivates partially purified, active collagenase, presumably by a direct degradative effect on the enzyme.

We have failed to produce latent collagenase by ex-

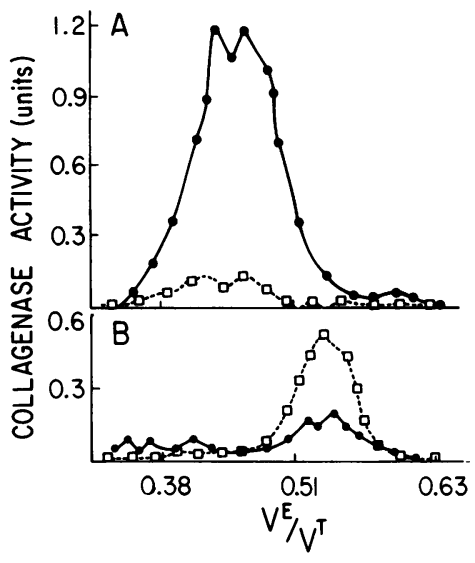

Figure 3 Molecular weight estimation of mersalyl-activated collagenase. (A) Approximately $170 \mathrm{U}$ latent collagenase was applied to AcA 54 column. Trypsin-activatable enzyme is indicated by the solid line. Spontaneously active enzyme by squares connected by dots. (B) After mersalyl treatment approximately $97 \mathrm{U}$ enzyme was passed through the same column equilibrated with $0.002 \mathrm{M}$ mersalyl.

haustive dialysis of mersalyl-activated enzyme against buffer which did not contain mersalyl. Included in these attempts were several in which mersalyl-activated collagenase was dialyzed extensively and then treated with trypsin $\left(10 \mu \mathrm{g} / \mathrm{ml}, 30 \mathrm{~min}, 22^{\circ} \mathrm{C}\right.$, followed by fourfold excess of soybean trypsin inhibitor). As in the fractions from the mersalyl column, this served only to decrease the total yield of enzyme.

\section{DISCUSSION}

An inhibitor of active collagenase has been found in medium from rheumatoid synovial cells cultured in the absence of serum and separated from latent collagenase. The latent enzyme, estimated mol wt 47,000, has been transformed to a lower mol wt $(33,000)$ active enzyme with either trypsin or mersalyl. Successful activation by the nonenzymatic mercurial compound, along with data showing recombination of active enzyme and inhibitor to give an activatable collagenase having the same estimated molecular weight as the original latent enzyme, has led us to the conclusion that latent rheumatoid synovial collagenase is an enzymeinhibitor complex. Latent enzyme of the same molecular weight was found in medium from cells cultured in 5\% serum, suggesting that the enzyme-inhibitor complex formed before release from cells when active collagenase could be complexed by serum inhibitors $\left(\alpha_{2}\right.$-macroglobulin and $\beta_{1}$-anti-collagenase $\left.(16,17)\right)$.

The experiments to determine whether latent enzyme could be activated or reduced in size by incubation with bacterial collagenase were generated by the work of Fiedler-Nagy et al. (18). They demonstrated that hydroxyproline-containing peptides were 
associated with human skin collagenase in crude preparations and suggested that enzyme-collagen fragment complexes might explain latency of this enzyme. Our data, however, indicated no effect of bacterial collagenase upon latent enzyme and have been interpreted to mean that the inhibitor is not a fragment of collagen or gelatin.

Our activation data are similar to those of Sellers et al. $(19,20)$. These investigators demonstrated activation of latent rabbit collagenase from numerous tissues using another mercurial compound (4-aminophenylmercuric acetate). Both analyses suffer from the inaccuracy of molecular weight estimations made by gel filtration chromatography. On AcA 54, active collagenase and inhibitor each had an apparent mol wt of 33,000 , yet the latent enzyme obtained by combining the two had an apparent mol wt of only 47,000 . It is possible that the inhibitor aggregates to run in polymeric forms on gel filtration columns. This would account for the molecular weight obtained for latent collagenase as well as for the multiple peaks of lower molecular weight containing trace inhibitory activity.

We have found consistently a small amount of active collagenase eluting with the peak of latent enzyme. This might represent a species of enzyme from which inhibitor has been dissociated sufficiently to expose the active site of collagenase but not to alter the apparent molecular weight of the enzyme. We do know that this high molecular weight active collagenase can be inhibited by addition of inhibitor (unpublished data). A similar "autoactivation" phenomenon has been reported by Stricklin et al. (21) after freeze-thawing or storage of human skin collagenase. It is likely that the active collagenase produced by trypsin is a different species than that generated by mersalyl and(or) autoactivation. The factors regulating autoactivation and the differences in susceptibility to and reversibility of inhibition of the different forms of active collagenase by inhibitors found in cartilage, bone, and tendon are under current investigation in our laboratory and those of others. Nonenzymatic activation may not be relevant to normal remodelling of connective tissue or pathologic states in vivo, but as first outlined by Reynolds et al. (22), the concept that latent enzyme is an expression of two separate bits of genetic information leads to the possibility that differences in the ratio of enzyme to inhibitor produced may be a significant factor in local tissue regulation of collagen resorption.

It is probable that collagenolytic systems are structured differently in different species and perhaps even in different tissues of the same species. Mouse bone collagenase, for instance, is apparently released as a zymogen $(23,24)$ which must be activated by limited proteolysis. It is possible that such a form of the rheumatoid synovial enzyme exists and is cleaved before complexing with inhibitor.

\section{ACKNOWLEDGMENTS}

We are indebted for helpful discussions and advice of Doctors A. J. Barrett, J. J. Reynolds, and D. Woolley. Mrs. Joan Lefebvre kindly prepared the manuscript.

This work was supported by U. S. Public Health Service grant AM 14780, by an Arthritis Clinical Research Center grant from The Arthritis Foundation, and by the New Hampshire Chapter of The Arthritis Foundation.

\section{REFERENCES}

1. Harris, E. D., Jr. 1976. Recent insights into the pathogenesis of the proliferative lesion in rheumatoid arthritis. Arthritis Rheum. 19: 68-72.

2. Krane, S. M. 1975. Collagenase production by human synovial tissues. Ann. N. Y. Acad. Sci. 256: 289-303.

3. Evanson, J. M., J. J. Jeffrey, and S. M. Krane. 1968. Studies on collagenase from rheumatoid synovium in tissue culture. J. Clin. Invest. 47: 2639-2651.

4. Bauer, E. A., A. Z. Eisen, and J. J. Jeffrey. 1971. Studies on purified rheumatoid synovial collagenase in vitro and in vivo. J. Clin. Invest. 50: 2056-2064.

5. Woolley, D. E., R. W. Glanville, M. J. Crossley, and J. M. Evanson. 1975. Purification of rheumatoid synovial collagenase and its action on soluble and insoluble collagen. Eur. J. Biochem. 54: 611-622.

6. Werb, Z., C. L. Mainardi, C. A. Vater, and E. D. Harris, Jr. 1977. Endogenous activation of latent collagenase by rheumatoid synovial cells. N. Engl. J. Med. 296: 10171023.

7. Dayer, J-M., S. M. Krane, R. G. G. Russell, and D. R. Robinson. 1976. Production of collagenase and prostaglandins by isolated adherent rheumatoid synovial cells. Proc. Natl. Acad. Sci. U. S. A. 73: 945-949.

8. Vater, C. A., C. L. Mainardi, and E. D. Harris, Jr. 1978. Binding of latent rheumatoid synovial collagenase to collagen fibrils. Biochim. Biophys. Acta. 539: 238-247.

9. Glimcher, M. J., C. J. Francois, L. Richards, and S. M. Krane. 1964. The presence of organic phosphorus in collagens and gelatins. Biochim. Biophys. Acta. 93: 585-602.

10. Harris, E. D., Jr., D. R. DiBona, and S. M. Krane. 1969. Collagenases in human synovial fluid. J. Clin. Invest. 48: 2104-2113.

11. McCroskery, P. A., J. F. Richards, and E. D. Harris, Jr. 1975. Purification and characterization of a collagenase extracted from rabbit tumors. Biochem. J. 152: 131-142.

12. Gross, J., and D. Kirk. 1958. The heat precipitation of collagen from neutral salt solutions: some rate-regulating factors. J. Biol. Chem. 233: 355-360.

13. Laemmli, U. K. 1970. Cleavage of structural proteins during the assembly of the head of bacteriophage T4. Nature (Lond.). 227: 680-685.

14. Chibber, B. A. K., K. G. Deutsch, and E. T. Mertz. 1974. Affinity chromatography of plasminogen. Methods Enzymol. 34: 424-432.

15. Werb, Z., and J. J. Reynolds. 1974. Stimulation by endocytosis of the secretion of collagenase and neutral proteinase from rabbit synovial fibroblasts. J. Exp. Med. 140: 1482-1497.

16. Werb, Z., M. C. Burleigh, A. J. Barrett, and P. M. Starkey. 1974. The interaction of $\alpha_{2}$-macroglobulin with proteinases. Biochem. J. 139: 359-368.

17. Woolley, D. E., D. R. Roberts, and J. M. Evanson. 1976 Small molecular weight $\beta_{1}$ serum protein which specifically inhibits human collagenases. Nature (Lond.). 261: 325-327.

18. Fiedler-Nagy, C., J. W. Coffey, and R. A. Salvador. 1977. 
Factors influencing the apparent molecular weight of collagenase produced by human skin explants. Eur. J. Biochem. 76: 291-297.

19. Sellers, A., E. Cartwright, G. Murphy, and J. J. Reynolds. 1977. An inhibitor of mammalian collagenase from foetal rabbit bone in culture. Biochem. Soc. Trans. 5: 227-229.

20. Sellers, A., E. Cartwright, G. Murphy, and J. J. Reynolds. 1977. Evidence that latent collagenases are enzymeinhibitor complexes. Biochem. J. 163: 303-307.

21. Stricklin, G. P., E. A. Bauer, J. J. Jeffrey, and A. Z. Eisen. 1977. Human skin collagenase: isolation of precursor and active forms from both fibroblast and organ cultures. Biochemistry. 16: 1607-1615.

22. Reynolds, J. J., A. Sellers, G. Murphy, and E. Cartwright. 1977. A new factor that may control collagen resorption. Lancet. II: 333-335.

23. Vaes, G. 1972. The release of collagenase as an inactive proenzyme by bone explants in culture. Biochem. J. 126: 275-289.

24. Eeckhout, Y., and G. Vaes. 1977. Further studies on the activation of procollagenase, the latent precursor of bone collagenase. Biochem. J. 166: 21-31. 